\title{
OS CONFESSORES DE MARX: A COMPANHIA DE JESUS E 0 \\ MARXISMO (1937-1982)
}

Iraneidson Santos Costa

Professor visitante do Mestrado em História da Universidade Estadual de Feira de Santana-UEFS.

\section{Resumo}

O ensaio confronta as principais interpretações do marxismo elaboradas pela Companhia de Jesus na Europa e no Brasil ao longo do século XX, de modo a acompanhar as transformações ocorridas numa das mais influentes ordens religiosas católicas: de tenaz aliada do antimodernismo e do anticomunismo ela se constituiria num dos segmentos mais ativos na tentativa de conciliação (teórica e prática) entre a doutrina social da Igreja e o marxismo.

\section{Pallavras-chave}

marxismo • Companhia de Jesus • pensamento social cristão.

\section{Abstract}

This essay confronts the main interpretations of marxism developed by the Society of Jesus in Europe and Brazil during the twentieth century in order to monitor the changes occurring in one of the most influential catholic religious orders: from great anti-modernist and anti-comunist she will be one of the most active segments in an attempt to reconcile (theoretical and practical) the social doctrine of the church and the marxism.

\section{Keywords \\ marxism $\bullet$ Society of Jesus $\bullet$ christian social thought.}




\section{Introdução}

No início de julho de 1978, um grupo de jesuítas brasileiros comprometidos com a pastoral popular ${ }^{1}$ se encontrou no Rio de Janeiro para um Encontro sobre Fé e Marxismo. Lamentavelmente, só temos desse encontro um relato tópico, ainda que bastante instigador. É como se se defrontassem, de maneira didática, duas das mais influentes correntes de interpretação do marxismo no interior da Companhia de Jesus, quem sabe até da própria Igreja Católica brasileira do final daquela década. Dos quatro dias de trabalho, os dois primeiros estiveram sob a responsabilidade do doutor em Filosofia e assessor do Centro de Estudos e Ação Social (Ceas), Tomás Cavazzuti (1937-), então já um ex-jesuíta. ${ }^{2}$ Foram seis exposições, cujo conteúdo podemos somente deduzir pelos títulos: 1) As diversas interpretações do marxismo; 2) A teoria social de Marx; 3) A crítica de Marx ao capitalismo; 4) A crítica do cristianismo enquanto ideologia; 5) A revolução social e 6) Cristãos e marxistas diante das exigências de uma nova sociedade.

Outro peso-pesado da marxologia jesuíta, o padre Henrique Cláudio de Lima Vaz (1921-2002) também foi palestrante. ${ }^{3}$ Ao descrever sua intervenção, o relator (anônimo) não mediu palavras: "No terceiro dia, o pe. Vaz apresentou o problema do diálogo cristianismo-marxismo dentro de uma visão culturalista,

1 Autodenominado de Pastoral Popular (PaPo), compunha-se de cerca de cinquenta jesuítas (em sua grande maioria padres, ainda que dele fizessem parte uns poucos irmãos) dispersos pelo país todo e cujo apostolado social foi muito ativo ao longo das décadas de 1970 e 1980. Uma análise minuciosa das origens, concepções e atuação do mesmo pode ser encontrada em Costa (2007).

2 Tomás Cavazzuti é italiano, tendo ingressado na Província Vêneta da Companhia de Jesus em 1955. Chegou à Bahia como escolástico (isto é, ainda estudante) em 1964, fez sua formação universitária no sul do país e concluiu seu doutorado na Pontifícia Universidade Gregoriana (PUG), de Roma, em 1971. No ano seguinte, entraria no Conselho Editorial dos Cadernos do Ceas, do qual foi redator entre 1973 e 1985, combinando as atividades editoriais com a docência de filosofia na UCSAL. Por volta de 1970 abandonou o sacerdócio e em 1985 deixou a revista, o Ceas e o Brasil, retornando à terra natal.

3 Nascido em Ouro Preto (MG), padre Vaz foi um dos principais filósofos brasileiros do século XX. Doutor em Filosofia pela PUG (1953), foi essencialmente um professor universitário, tendo ensinado por quase 50 anos nas faculdades de Filosofia e Teologia da Companhia de Jesus (em Nova Friburgo, Rio de Janeiro e Belo Horizonte) e na Universidade Federal de Minas Gerais (UFMG). Simultaneamente a uma prolífica carreira acadêmica, com mais de 10 livros e 150 artigos publicados, teve, especialmente na década de 1960, uma destacada atuação junto aos movimentos católicos leigos, tendo sido, durante muitos anos, um dos principais assistentes da Juventude Universitária Católica (JUC) nacional e um dos "padres mais ativos e avançados do Brasil nesse momento" (cf. Löwy, 2000, p. 232). Em 2003, um ano depois de sua morte, foi inaugurado o Centro de Promoção Humana Padre Vaz, em Belo Horizonte (MG). Para sua autobiografia, consultar Vaz (1976b). 
bastante alienada, suscitando muita reação por parte da maioria". ${ }^{4}$ Assim, depois da participação do dominicano Carlos Alberto Libânio Christo (mais conhecido como frei Betto), que, sempre segundo o escriba não identificado, teria apresentado as "convergências profundas" entre essas duas visões de mundo, "quando os dois se põem em uma perspectiva, não ontológica, e sim revolucionária", conclui-se que "o encontro serviu para libertar de um certo medo frente ao marxismo, mostrando as razões disso" (idem). Não temos conhecimento da reação do pe. Vaz ao tempo dos acontecimentos, mas sabemos dos seus sentimentos anos depois, numa correspondência reservada:

A reação por parte da maioria dos jesuítas, sobretudo dos membros do Ceas de Salvador, tendo à frente o seu "ideólogo", o ex-jesuíta Tomás Cavazzuti, foi extremamente violenta! Eles acreditam, com a fé ou o fanatismo de um "ayatollah", que o marxismo é uma ciência e a única ciência capaz de explicar a "formação social capitalista”! Compreendi que o problema ali não era o da discussão teórica mas do discurso de legitimação em face dos militantes de esquerda com os quais estão engajados. ${ }^{5}$

Como entender um tratamento tão pouco cortês a um dos maiores filósofos brasileiros, mestre, de certa forma, de várias gerações de jesuítas pelo Brasil afora? Um parricídio intelectual? Não entraremos no mérito das moções pessoais, procurando compreender esta rivalidade na perspectiva de um embate teórico, com amplas derivações práticas, entre as duas mais influentes leituras do marxismo na Companhia de Jesus do período. Uma arqueologia do pensamento social jesuítico se faz necessária, o que nos exigirá uma breve digressão aos anos 1930, ponto de partida desta "marxologia jesuítica". Para fazê-lo, não apenas acompanharemos em largos traços o longo (e, no mais das vezes, conflituoso) percurso dos companheiros em direção ao marxismo como também recolheremos algumas das contribuições do antimarxismo aí produzido. De fato, é bom não perder de vista que a Companhia de Jesus era, no princípio do século XX, aliada da antimodernista, integrista e monárquica Ação Francesa, esta intransigente adversária do socialismo, do liberalismo e da democracia que, "se soube resistir ao nazismo, nem sempre recusou (...) as investidas do fascismo italiano

4 Relatório [Rio de Janeiro, jul. 1978]. Arquivo da Casa da Memória Popular, Ceas (Campo). Salvador, Bahia.

5 ASJS - Arquivo do Secretariado de Justiça Social. Carta do pe. Vaz ao pe. Calvez. Rio de Janeiro, 26/11/1979. Caixa Marxist analysis. Roma, Itália, p. 11. 
ou do franquismo espanhol" (Lacouture, 1993, p. 510). O elo entre a Igreja Católica e o fascismo começaria a se romper apenas a partir de 1926, quando Pio XI (1922-1939) condenou a Ação Francesa, incluindo no Index a maioria das obras de seu mais destacado representante, Charles Maurras (1868-1952).

\section{A nova teologia}

Ousamos dizer que tudo começou na França. Foi daí que brotou a Nouvelle Théologie, movimento responsável pela renovação do pensamento cristão a partir da década de 1930. Desenvolvida em duas escolas, a jesuíta de Fourvière (Lyon) e a dominicana de Le Saulchoir (Paris), "articulou a fé com a história e desenvolveu uma verdadeira teologia da história, redescobrindo a tradição cristã, relendo a Revelação em seu dinamismo histórico e renovando integralmente a metodologia teológica ao sair da via dedutiva e ao enveredar pela via indutiva de produção teológica" (Gonçalves e Bombonatto, 2004, p. 72). E se os "novos teólogos”, como os jesuítas Henri de Lubac (1896-1991) e Jean Daniélou (19051974) e os dominicanos Marie-Dominique Chenu (1895-1990) e Yves-Marie Joseph Congar (1904-1995), seriam acusados pela Encíclica Humani Generis (sobre opiniões falsas que ameaçam a doutrina católica), publicada em 1950 por Pio XII (1939-1958), de minar os ensinamentos tradicionais a respeito do pecado original, da graça e da liturgia, sofrendo, em razão disso, graves restrições ao seu exercício intelectual, a geração da qual fizeram parte seria marcante. ${ }^{6}$

No campo da reflexão social, o grande nome inegavelmente foi o de Gaston Fessard (1897-1978), "um dos nossos heróis”, como gostava de dizer pe. Vaz. Nascido em Elbeuf, no nordeste da França, Fessard licenciou-se em Letras e Filosofia, tendo sido professor da Faculdade de Teologia de Fourvière e secretário de redação de Recherches de Sciences Religieuses. Por sugestão de seu amigo, Gabriel Marcel (1889-1973), escreveu a corajosa Pax Nostra: examen de conscience international (Paris: Grasset, 1936) e, logo depois, já na iminência da invasão alemã, Épreuve de force: réflexions sur la crise internationale (Paris:

\footnotetext{
6 De Lubac, por exemplo, foi afastado do ensino, com mais quatro jesuítas, em 1950 (a propósito, uma obra sua lançada em 1945 pela editora parisiense Spes, Le drame de l'humanisme athée, consagrava o primeiro capítulo à analise do marxismo). Após as suspeições, admoestações e restrições dos anos 1940 e 1950, o pontificado de João XXIII haveria de "absolvê-los", convocando-os para participar do Concílio Vaticano II na condição de peritos. Ironicamente, com exceção de Chenu, todos morreriam cardeais: Daniélou criado por Paulo VI no consistório de abril de 1969, De Lubac e Congar por João Paulo II, o jesuíta em 1983, o dominicano em 1994.
} 
Bloud et Gay, 1939), dois enfáticos libelos antifascistas num momento em que o mundo (e a Companhia de Jesus) ainda não haviam se dado conta da extensão do perigo. Outro de seus amigos e admiradores, o sociólogo liberal Raymond Aron se referia a ele como "o diretor de consciência dos franceses".?

Coube a ele inaugurar o diálogo com os marxistas mediante a publicação de duas obras seminais: La main tendue: le dialogue catholique-communiste est-il possible? (Paris: Grasset, 1937) e Le communisme va-t-il dans le sens de l'histoire? (Paris: Psyché, 1948). ${ }^{8}$ Uma de suas maiores contribuições consistiu em desmoralizar o discurso antibolchevista, apontando como ele não passava, muitas das vezes, de máscara para a defesa do perverso anti-humanismo nazi-fascista, o que se formalizou na fundação, em 1941, dos abertamente anticolaboracionistas Cahiers du Témoignage Chrétien, cujo primeiro número sairia com o sugestivo título de "France, prends garde de perdre ton ame!" [França, cuida para não perderes a tua alma!]. Sua ousadia não ficaria impune: Fessard foi obrigado a passar boa parte da Segunda Guerra Mundial "exilado" em Lyon, então zona não-ocupada pelos nazistas, uma vez que, na França de Vichy, suas obras faziam parte da famigerada "lista Otto" (em referência ao embaixador alemão Otto Abetz), relação de autores judeus e/ou comunistas que "envenenavam a opinião pública francesa" e, portanto, estavam proibidos de ser publicados pelas editoras ou sequer discutidos por outros autores.

Um dos mais criativos hegelianos franceses do pós-guerra, Fessard criticou com igual veemência os "progressistas" de inspiração tomista e personalista, infundindo a dialética histórica nas veias do humanismo social cristão. Para ele, esta era a única via de legitimação da dimensão cristã na vida moderna, em aberta oposição ao que considerava a degeneração das filosofias sociais baseadas no tomismo, então representadas pelas obras de Emannuel Mounier (1905-1950) e do recém-convertido Jacques Maritain (1882-1973). Um pouco mais jovem que Fessard, Mounier foi mentor do personalismo cristão, que se

\footnotetext{
7 “Gaston Fessard et l'actualité historique", conferência realizada por Raymond Aron em Roma, em 18/05/1983, cinco anos depois da morte de Fessard (cf. Lacouture, 1993, p. 374).

8 É bom não perder de vista que, desde o final do século XIX, os jesuítas vinham criticando o marxismo. Por exemplo, La Civiltà Cattolica, o primeiro periódico da Companhia de Jesus, fundado em 1850 sob os auspícios do papa Pio IX (1846-1878), publicou, entre 1897 e 1898, uma série de artigos sobre o marxismo, dos quais merece destaque "Le rivendicazione operaia e il socialismo scientifico", no qual Marx é apresentado como autor de vários "sofismas" e, apesar de dotado de uma vasta erudição no que diz respeito à literatura econômica inglesa, haveria assumido "uma dialética hegeliana pérfida e flexível” (apud Calvez, 2001).
} 
pretendia a síntese entre o cristianismo e o socialismo. A partir de Esprit, revista que fundou, defendeu a prioridade absoluta do ser humano diante das pressões materiais e das instituições desumanizantes da vida social, afirmando que, no comunismo, o sobrenatural era deturpado em simples superestrutura de maneira a evitar a cilada do idealismo, eliminando, assim, qualquer perspectiva cristã, pois um suposto comunista-cristão seria "um comunista total, só nominalmente cristão!". ${ }^{9}$ Entende-se a vibrante contraposição de Fessard, sobretudo porque o personalismo foi a porta de acesso de muitos católicos ao marxismo. ${ }^{10}$

Para além do intenso debate intelectual havia também a tradição francesa de envolvimento direto do laicato na política, ainda que num modelo paternalista e a partir de uma concepção corporativa de sociedade (classes sociais dispostas em corporações mutuamente respeitosas), devidamente fomentada por jesuítas "ativos" como Henri-Joseph Leroy (1847-1971), Stanilas du Lac (1835-1909), fundador do Syndicat de l'Aiguille ${ }^{11}$ e, sobretudo, Gustave Desbuquois (1869-1959), um filho de pedreiro, criador, em Reims, em 1903, da Ação Popular, inspirada nos ensinamentos de Leão XIII (1878-1903) e responsável pela realização de várias semanas sociais em Paris e pela disseminação de centros de ação social por todo o país. Aos olhos do Vaticano e da ala monarquista da Companhia de Jesus francesa de então, seu projeto era "quase bolchevista" (cf. Lacouture, 1993, p. 384). ${ }^{12}$

Sua atuação não teve impacto apenas no continente europeu, atravessando o oceano e repercutindo no movimento operário do Canadá francês: La participation

9 Communistes chrétiens. Feu la Chrétienté,jun. 1947, p. 141-142 (apud Calvez, 1959, vol. 2, p. 354).

${ }^{10}$ Uma análise sucinta deste debate pode ser encontrada em Vaz (1977) e Santos (1989), ainda que este último esteja mais preocupado em recolher a contribuição do pensamento maritainista. De qualquer modo, uma vez vencido Hitler e encerrada a guerra, Fessard publicaria, em 1945, nos mesmos Cahiers du Témoignage Chrétien um outro manifesto, chamado "França, cuida para não perderes a tua liberdade!", no qual volta suas baterias para o novo inimigo, a saber, o marxismo e seus agentes comunistas...

${ }^{11}$ Consistia numa sociedade de crédito para costureiras, em sua grande maioria adolescentes e jovens, que se espalhou pela França, a ponto de contar, em 1901, com mais de 2.220 integrantes, sendo que, somente em Paris, seus dois restaurantes (exclusivos para os membros) haviam servido até então mais de um milhão de refeições (cf. Drummond, 1910).

${ }^{12}$ Por esta mesma época, na Alemanha, o pe. Heinrich Pesch (1854-1926) procurava fazer avançar o pensamento social católico através do solidarismo. Seu esforço neste sentido ficou registrado nos cinco volumes de seu Lehrbuch der Nationalökonomie [Manual sobre a Economia Nacional], publicado originalmente em 1905 (cf. Czerny, s.d.). Em linhas gerais, o solidarismo consistia numa "doutrina baseada no princípio da solidariedade real entre a pessoa e a comunidade, e de um sistema social, político e econômico intermediário entre a descentralização atomizante do individualismo e a centralização monolítica do coletivismo", conforme definição do sociólogo jesuíta Fernando Bastos de Ávila (1978, p. 560). 
des travailleurs à la vie de l'entreprise, livro escrito por Desbuquois em parceria com Pierre Bigo, outro jesuíta da Ação Popular parisiense, converteu-se numa espécie de "bíblia" para os padres e capelães envolvidos no trabalho social junto à classe trabalhadora, estando na base das jornadas sacerdotais de estudos sociais de 1947 e da greve dos operários do amianto ocorrida em Quebec dois anos depois. Por conta disso, ambos haveriam de sofrer uma intensa campanha movida por sindicatos patronais e grupos católicos conservadores desejosos de obter a condenação de suas ideias e práticas "socialistas" por parte de Roma. ${ }^{13}$

\section{A marxologia jesuítica}

Seria somente na década de 1950 que a leitura jesuítica de Marx experimentaria seu primeiro grande florescimento, com a publicação de obras fundamentais: Der dialektische Materialismus: seine Geschichte und sein System in der Sowjetunion (1952), de Gustav Andreas Wetter (1911-1991); Marxisme et humanisme: introduction à l'oeuvre économique de Karl Marx (1953), do já citado Pierre Bigo; Le marxisme en Union Soviétique: idéologie et institutions leur évolution de 1917 a nos jours (1955) e De Karl Marx a Mao Tsé-Tung: introduction critique au marxisme-léninisme (1959), ambos de Henri Chambre (1908-1994), e, por fim, Marxisme et liberté (1956) e La pensée de Karl Marx (1956), de Jean-Yves Calvez (1927-). A primeira dessas obras, o livro de Wetter, consiste num grosso volume de mais de 600 páginas baseado em documentação exaustiva e que submetia o marxismo soviético "a uma crítica cuja serenidade se alia a um rigor que não conhece desfalecimento", segundo a recensão do pe. Vaz (1959a). ${ }^{14}$ Seu autor, natural de Viena, terminou se convertendo em especialista na filosofia soviética: cursou, nos anos 1930, o Pontifício Colégio Russo, de Roma (do qual se tornaria reitor entre 1947 e 1954), fundou em 1947 e dirigiu por muito tempo o Centro de Estudos Marxistas da PUG e, ao longo de décadas, lecionou História da Filosofia Russa

\footnotetext{
${ }^{13}$ Recentemente, a historiadora Suzanne Clavette lançou um livro sobre a atuação desses padres junto ao movimento operário canadense do período (Participation des travailleurs et réforme de l'entreprise Québec: PUL, 2006). É possível consultaruma sinopse da pesquisa emwww.pulaval.com.

${ }^{14} \mathrm{Na}$ década seguinte, não só este como outros estudos de Wetter sobre o materialismo alcançariam um certo sucesso editorial, com diversas edições e traduções para vários idiomas, a exemplo de Le matérialisme dialectique. Bruges: Desclée de Brouwer, 1962, Filosofia e ciências da natureza na União Soviética. Porto: Livros do Brasil, 1963, Idéologie soviétique contemporaine. Paris: Payot, 1965 e Hombre y mundo en la filosofia comunista. Buenos Aires: Sur, 1965.
} 
no Pontifício Instituto Oriental, instituição igualmente administrada pelos jesuítas da Cúria Romana. A propósito, seu livro inaugural resultou de uma série de conferências pronunciadas no verão de 1945 no Pontifício Instituto Oriental, e "rigorosa" é o mínimo que se pode dizer da crítica procedida:

Uma exposição breve da terminologia hegeliana do materialismo dialético suscita no leitor a impressão de que, por trás desta formulação, se oculta algo "profundo". Que esta impressão é falsa se torna evidente, em primeiro lugar, na exposição detalhada das posições e argumentos do materialismo dialético soviético (...), [a qual] poderia aduzir um número suficiente de provas para justificar seu propósito de que, na filosofia soviética de hoje, já não resta nada da dialética real, que se trata bem mais de um evolucionismo naturalista adornado pela terminologia dialética (Wetter, 1963, p. 11, tradução minha).

Os demais livros acima citados são de autoria de intelectuais ligados à Ação Popular, cujas organizações, aliás, teriam servido de modelo aos centros sociais (Cias) fundados por jesuítas na América Latina décadas mais tarde, como reconhece o próprio Bigo. ${ }^{15}$ De todo modo, estes autores já vinham publicando alguns artigos sobre o marxismo desde a década de 1940 em diversos periódicos franceses, sobretudo em Travaux de Action Populaire, Economie et Humanisme, Chronique Sociale de France e na jesuíta Études. Bigo, por exemplo, havia escrito em 1947 um texto em Travaux de Action Populaire chamado "Débat sur le marxisme" e, antes de sua obra maior, Chambre tinha produzido pelo menos seis trabalhos analisando a relação entre o marxismo e o comunismo. Doutor em Ciências Econômicas, Bigo merece uma atenção especial de nossa parte, já que foi professor e diretor do Instituto Latino-Americano de Desenvolvimento (Ilades), de Santiago do Chile (1966-1969), coordenador dos Cias latino-americanos (1968-1972), diretor da seção social do Instituto de Pastoral do Conselho Episcopal Latino-Americano (Celam) em Medellín (1974-1978), e, por um semestre, fez parte da equipe do Instituto Brasileiro de Desenvolvimento (Ibrades), importante centro social dos jesuítas da Província Centro-Leste brasileira. Editado em 1953, Marxismo e humanismo foi redigido entre 1943 e 1951. Antigo padre-operário, Bigo (1966, p. 7) conta no prefácio à

\footnotetext{
${ }^{15}$ Cf. Carta de Pierre Bigo a Jean Lacouture, 16/03/1992, apud Lacouture, 1993, p. 385 (nota). A propósito, Bigo foi diretor da Ação Popular entre 1952 e 1960.
} 
edição brasileira que, antes de encontrar o marxismo "como padre, ao trabalhar numa fábrica, busquei-o na própria fonte, em $O$ capital".

Trata-se de uma reinterpretação de $O$ capital através de categorias filosóficas. Ele explica que havia inicialmente tentado proceder a uma análise econômica de Marx mas, diante da impossibilidade de "encontrar uma coerência nos primeiros capítulos" do referido livro, empreendeu uma leitura filosófica, o que teria lhe desnudado pouco a pouco a substância da obra de Marx. Ao destacar as razões para rejeitar o sistema marxista, Bigo apresenta a ideia que permitiria reconstruí-lo, conduzindo-o a propor futuramente "uma doutrina social, fundada sobre uma teoria do valor e do capital, que rejeite os grandes erros do marxismo, mas faça justiça à sua verdade" (idem, p. 47). Seu estudo visava, portanto, restituir, em sua pureza, o verdadeiro humanismo de Marx, que "é de tal modo essencial à economia política marxista que não se pode arrancá-lo sem destruir o contexto. (...) É impossível interpretar, num sentido estreitamente econômico, o hino ao trabalho que constitui a síntese marxista. Não é a produção em si que é glorificada, é o homem no trabalho" (ibidem, p. 185).

$\mathrm{O}$ argumento central é o seguinte: apesar de Marx não recorrer à ideia de uma natureza espiritual e moral do homem, nem a categorias éticas, metafísicas ou religiosas, censuradas por conta de sua posição materialista e por coerência a todo o desenvolvimento anterior de seu pensamento, por qualquer ângulo que se aborde sua economia política, se é forçado a concluir que uma afirmação de ordem metafísica - a do sujeito humano - a atravessa, ou seja, toda uma afirmação autêntica do homem em sua dignidade essencial. Perdoem-nos a citação longa, mas necessária para a compreensão precisa da abordagem de Bigo:

Um ato de fé implícito no primado do homem sobre as coisas, do espírito sobre a matéria. (...) Não seria preciso estender muito a reflexão marxista para lhe descobrir um sentido religioso. O proletário está no centro da história, como Cristo entre o Começo e o Fim dos Tempos. Há, em Marx, uma Gênese: o ato criador, que é o trabalho, está estreitamente ligado ao ato da alienação do homem no trabalho. O pecado está nas próprias origens da humanidade. Há também um Apocalipse. $\mathrm{O}$ homem deve reencontrar, através de uma catástrofe, o paraíso perdido. (...) Marx não pode, pois, evitar de colocar o homem no absoluto. A ideia de uma transcendência está no fundo de todas as suas teses. É por vezes surpreendente, e frequentemente trágico, seguir os passos de mágica que permitiram a Marx exprimir um pensamento tão fundamentalmente metafísico, e mesmo religioso, recalcando a ideia de transcendência que nele se encontrava implicada (ibidem, p. 193-195). 
Poderíamos prosseguir longamente aqui com as analogias de Bigo: O capital como a "Bíblia marxista", Marx como o judeu das Escrituras que é transpassado por um sopro profético etc. O que temos, contudo, parece suficiente para entender a irritação que tais posições causaram nos comunistas franceses: um padre jesuíta se pondo de psicanalista (ou seria confessor?) de Marx! Deve ter sido por passagens assim que um destes intelectuais, Georges Cogniot, desprezou o livro, acusado de se constituir numa "trapaça intelectual"... De qualquer maneira, Bigo está disposto, na sua análise, a imputar grandeza ao pensamento marxista, por sua recusa da dominação e por seu projeto de uma economia nas mãos do homem. Mas também aponta sua fraqueza, na negação do que é para-além do homem. Daí porque levanta a suspeita sobre a ambiguidade do projeto marxista: "O marxismo é um humanismo ou é, simplesmente, uma técnica superior de produção, um capitalismo mais eficaz?" (ibidem, p. 275). Sua obra conclui-se com a esperança de que o marxismo pudesse abrir-se à ideia de que as transformações estruturais da sociedade não seriam obtidas apenas através das "místicas temporais" como também por meio das "forças espirituais que mudam o próprio homem", numa promissora convergência entre duas das maiores forças existentes no mundo: a corrente social, no plano temporal, e a corrente cristã, no plano espiritual.

Todavia, à Companhia de Jesus não interessava unicamente o estudo sistemático do marxismo, como também suas possíveis aplicações e desdobramentos concretos. O padre geral Wladimir Ledochowski (1866-1942), polonês austero que governou a Ordem nas difíceis conjunturas das duas grandes guerras mundiais, dirigiu em 1934 a todos os jesuítas do mundo uma "Carta sobre a necessidade e o meio de opor-se eficientemente ao ateísmo moderno" e, no ano seguinte, criou na Cúria um Secretariado Geral encarregado de coordenar este esforço, nomeando para sua direção o jesuíta canadense Joseph Ledit (aliás, seu futuro biógrafo). Este Secretariado publicou, até a Segunda Guerra Mundial, Lettres de Rome, um periódico amplamente difundido cuja missão consistia em "informar aos sacerdotes e leigos da Ação Católica sobre a ação religiosa dos ateus militantes do mundo" (Calvez, 2001).

Um dos membros deste Secretariado, o economista Henri Chambre, editor do Instituto de Ação Popular e antigo "resistente" (mais tarde chegaria a ser professor da Sorbonne), estudou o russo durante três anos para tal empreitada. $O$ marxismo na União Soviética, lançado em 1955 pelas edições Le Seuil, parte da análise do problema da ideologia em Marx, acompanhando sua evolução através dos escritos de Lênin até o momento em que, pela vitória da Revolução de 1917, a ideologia marxista passou a exprimir a superestrutura de um Estado socialista. 
Sua conclusão, na linha de interpretação proposta anos antes por Wetter, é que, dada a importância atribuída ao Estado e ao Partido, o problema da ideologia encontrava-se "em nítida oposição com a concepção original de Marx. Melhor, ela assinala uma contradição que minava já a própria concepção marxista da Dialética" (apud Vaz, 1959a, p. 83). ${ }^{16}$ Escutemos o próprio Chambre:

Do exame da própria evolução da ideologia soviética desde 1917 a nossos dias se desprende, efetivamente, uma (...) conclusão. A fidelidade às teses centrais de Karl Marx foram postas à prova: tanto a fidelidade à Crítica do programa de Gotha como a fidelidade às teses da Ideologia alemã, do prefácio à Contribuição à crítica da economia política e de $O$ capital. A primeira fidelidade desapareceu já que a ideologia que propugna não corresponde em nada à realidade do regime que instituiu a Nova Política Econômica (NEP) e os começos da socialização da economia. Enquanto a segunda, ao desenvolver-se e manter-se graças ao apoio de um partido único poderoso, manifesta a contradição subjacente à obra do mesmo Marx. A morte da dialética inscrita na obra de Karl Marx se perfila no horizonte do desenvolvimento da ideologia soviética (1960, p. 437-438, tradução minha).

Quando, no entanto, Chambre quis verificar suas hipóteses in loco "viu recusarem-lhe por três vezes a autorização de partir para o Leste..." (Lacouture, 1993, p. 371). Por fim, fechando esta magnum opus, o projeto mais ousado de todos foi indubitavelmente o livro de Jean-Yves Calvez, provavelmente o mais próximo (e influente) colaborador do pe. Pedro Arrupe (1907-1983), que o fez um de seus assistentes gerais (eram quatro), nomeou-o provincial da França logo em março de 1967 (dois anos depois de eleito) e a quem delegou missões importantíssimas para a definição dos rumos da Companhia de Jesus naquele decisivo generalato (1965-1981). ${ }^{17}$ Mas isso só ocorreria na década seguinte.

\footnotetext{
${ }^{16}$ Outro livro de Chambre (1961, p. 13), publicado no início da década seguinte, seguiria esta mesma linha, considerando que "as oposições do cristianismo ao comunismo manifestam a oposição de duas concepções de homem inconciliáveis" (tradução minha). Por outro lado, como prova da significativa influência exercida por este autor sobre o pensamento do pe. Vaz, ele não apenas resenharia a obra inaugural de Chambre como traduziria e prefaciaria anos depois outra obra do mesmo, De Marx a Mao-Tsé Tung, quando procura esclarecer seu foco de interesse: "O debate sobre o marxismo é um grande debate humano e cristão. Cumpre elevá-lo, ao menos nas suas formas mais sérias, acima do nível de uma subliteratura que hoje nos invade e que parece deferir a última instância a uma concepção policial e irracional da história”.

${ }^{17}$ Para citar apenas uma delas, em 1971, Calvez foi nomeado para presidir a comissão responsável pela ampla consulta que confirmaria a vocação social e a democratização da Companhia de Jesus.
} 
Por enquanto, é somente o filósofo, professor de sociologia e diretor do Instituto Católico de Paris quem efetua, em dois alentados volumes, uma meticulosa exposição do humanismo marxista. Seu ponto de partida é a continuidade entre a concepção dialética expressa nos escritos da juventude de Marx, sobremaneira nos Manuscritos econômico-filosóficos de 1844, e a que é aplicada nas obras de maturidade. Com base nisso, ele retoma as conclusões de Chambre, afirmando que a filosofia oficial da União Soviética, a concepção engelsiana-leninista da dialética da natureza, seria incompatível com o fato dialético fundamental segundo Marx, que é a unidade dialética homem-natureza. Calvez (1959, vol. 1, p. 13) não poupa, porém, o velho pensador alemão das distorções das revoluções que ele inspirou: "Todos os acontecimentos do comunismo se devem, de algum modo, referir às ideias de Marx e ao método que delas logicamente deriva. (...) Se constituem desvios, se parecem contraditórios, é simplesmente porque também a doutrina a que se referem tem desvios e é contraditória”.

Ou seja, as antinomias perceptíveis nos sucessores (Engels, Lênin, Stálin e Kruschev, assim arrolados) decorreriam dos conceitos que Marx "só imperfeitamente conseguiu conciliar", de maneira que "as contradições teóricas do marxismo vieram naturalmente a surgir na evolução da ideologia" (idem, vol. 1, p. 15, nota 3). A questão de fundo, porém, estava na qualificação de um humanismo marxista, tema da obra de Bigo. Conforme diz Calvez, residiria aí uma das insanáveis contradições do pensamento marxista, precisamente entre o ateísmo prático e o ateísmo crítico, terminando por invalidar a ambos. Ele não tem dúvida de que é precisamente por ser humanismo que o comunismo é também ateísmo, de que a concepção marxista do homem e da sua realização é inseparável da supressão prática da religião e da negação teórica de Deus, mas insiste na contradição: o homem marxista prova o ateísmo (prático) na sua própria experiência de homem socialista, mas esta experiência apenas se tornou possível a partir de um ateísmo (teórico) que se exprimia pela crítica da alienação religiosa.

Chega-se, então, a um paradoxo: "o ateísmo é simplesmente o avesso de tal humanismo" (ibidem, vol. 2, p. 304). Como se percebe, Calvez não é tão otimista quanto Bigo no tocante às possibilidades deste humanismo. De acordo com ele, apesar de interessante, a estratégia seguida por seu companheiro de Ação Popular de transportar categorias filosóficas da análise econômica de Marx para categorias de significação diretamente ética seria bastante discutível, e o teria impedido de alcançar seu objetivo, a saber, "a verdadeira crítica imanente da filosofia marxista", além de confundir o humanismo naturalista do marxismo com 
um suposto (ou desejado) humanismo personalista. As conclusões daí derivadas tornam mais distante qualquer diálogo, uma vez que Calvez avalia como correta a forma pela qual a Igreja vinha tratando o marxismo, "que conhece bem", isto é, "como um sistema que irredutivelmente a contradiz e nega totalmente" (vol. 2, p. 380). No que, aliás, não fazia mais do que confirmar o magistério oficial da Igreja Católica, quando, no Decreto do Santo Ofício, baixado por Pio XII anos antes, em 1949, rejeitava o marxismo por anticristão, não apenas antirreligioso.

A sensação a que se é levado é que, simplesmente, "toda a obra de Marx se tornou inteiramente inútil” (vol. 2, p. 435). Mas é só uma sensação. Após ter comprovado (ou, pelo menos, julgado fazê-lo) a incoerência desse sistema filosófico, Calvez prepara o seu resgate, justamente a partir da filiação hegeliana de Marx. É essa herança que lhe fará identificar no marxismo um manancial de "virtudes cristãs enlouquecidas", na medida em que o próprio hegelianismo é a mais exitosa transmutação das verdades cristãs em verdades filosóficas. Com isso, a "verdade" do marxismo se situaria na admissão de um fundamento religioso de toda a existência humana. Calvez não tem pejo de anunciar a Igreja como a sociedade perfeita pretendida pelo comunismo, a fé (não mais a revolução) como a forma de atingi-la e a sociedade eclesial como a realização plena da síntese do fim da história numa história continuada, de maneira mais plena que qualquer sociedade comunista, pois que sem contradição, "graças às excepcionais condições de mediação social, que é o Corpo místico de Cristo" (vol. 2, p. 392). O remate chega a ser risível: "O esforço de Marx pouco adiantou, mas vale a pena recomeçá-lo, com mais amplas perspectivas” (vol. 2, p. 447). Malgrado as distinções anunciadas, a obra de Calvez finaliza de um jeito que lembra muito o estilo de Bigo. E os jesuítas, cuja fama de confessores de papas e monarcas é proverbial, definitivamente ampliaram sua lista de clientes. Outro parágrafo de fôlego se impõe:

Só Cristo pode ser o verdadeiro mediador que Marx procurava. Só Cristo pode operar a revolução salvadora, que Marx em vão esperava do proletariado. Assim como a revolução, segundo Marx, deve ser o ato essencial do proletariado, assim a morte de Cristo - Vencedor da Morte - é o ato essencial da sua vida humana. (...) Esta sociedade, realidade sempre presente da mediação de Cristo, é a Igreja, corpo místico de Cristo. É esta uma sociedade sem classes, onde o fermento de divisão social é radicalmente eliminado. Se o proletariado marxista se devia tornar no homem total, Cristo tornou-se, efetivamente, toda a humanidade (ibidem, vol. 2, p. 391). 
Diante dessa massa crítica jesuítica, o Partido Comunista Francês (PCF) sentiu-se obrigado a reagir, organizando em abril de 1957 uma conferência contraditória pública, na qual intelectuais marxistas franceses (como Henri Denis e Roger Garaudy, entre outros) "responderiam a seus críticos católicos". ${ }^{18}$ No entanto, Bigo, Chambre e Calvez recusaram o convite por conta da suspeita "de que o debate declinaria certamente da serenidade objetiva que convém à pesquisa científica, (...) numa reunião onde a propaganda tinha todas as possibilidades de ficar com a última palavra" (ibidem, vol. 2, p. 85). As impressões de um dos envolvidos, Pierre Bigo, ajuda a entender a (quase) impossibilidade de um diálogo efetivo. No prólogo à $3^{\mathrm{a}}$ edição de Marxismo e humanismo, publicada em 1961, ele comenta o episódio:

Tínhamos esperado que o retorno ao verdadeiro Marx permitisse um diálogo frutuoso com os próprios marxistas. Foi deste lado que as reações foram as mais decepcionantes. (...) Para os militantes do Partido [Comunista Francês], a obra devia ser pura e simplesmente desacreditada. (...) [Assim], o julgamento foi feito à revelia, os "autores católicos ausentes", desencorajados pela fraqueza das respostas até então dadas pelos comunistas a suas sérias questões (Bigo, 1966, p. 37).

Realmente, não poderia prosperar um diálogo no qual pelo menos uma das partes (provavelmente, ambas) presume deter "o verdadeiro Marx" e, o que é pior, recusa um confronto por saber de antemão o que irá acontecer... Aliás, contagiado por esse estado de espírito, o tradutor do livro de Calvez, o padre (e também jesuíta) Agostinho Veloso, numa atitude que rompia com uma estabelecida tradição de discrição, após percorrer silenciosamente as quase mil páginas da obra do seu companheiro de Jesus, não resistiu à tentação da autoria, aduzindo cinco parágrafos de sua própria lavra depois de ter colocado o ponto final. Na verdade, trata-se de um comentário à coletânea organizada pelo PCF. Demos voz ao tradutor, ao menos uma vez:

Esta obra de Calvez saiu à luz em 1956. Os comunistas assustaram-se com ela e em vão tentaram responder-lhe. (...) Os marxistas, incapazes de ultrapassar o primarismo desta negação absurda [de Deus], não hesitam em preferir os caminhos do desespero aos caminhos da esperança. Cristianismo e marxismo são duas

\footnotetext{
${ }^{18}$ A coletânea, com artigos de Denis, Garaudy, Cogniot e Guy Besse, foi publicada como Les marxistes répondent à leurs critiques catholiques (Paris: Editions Sociales, 1957).
} 
mundividências opostas, com duas linguagens diferentes, sem possibilidade de passagem de um lado para o outro. Tanto o comunista que abraça o catolicismo, como o católico que passa ao marxismo, fazem-no não em virtude de um diálogo entre duas mundividências, com as suas respectivas linguagens, mas sim trocando uma mundividência pela outra e uma linguagem pela outra. Entre o SIM católico e o NÃO comunista, não há meio termo, nem lugar para qualquer compromisso (apud Calvez, 1959, vol. 2, p. 448, nota a).

Diante de tal nível de ruído na comunicação, com tão entranhadas incompreensões de lado a lado (até do tradutor), pareceria só restar a alternativa de encerrar o diálogo, mal iniciado, e decretar: fim de papo! Muito pelo contrário. O livro de Calvez, por exemplo, terá um impacto enorme em toda uma geração de religiosos e leigos cristãos brasileiros, muitos dos quais serão iniciados na literatura marxista justamente a partir desta obra. Todavia, mesmo tendo sido bastante lida e discutida nos seminários e casas de formação de algumas ordens religiosas mais progressistas (como dominicanos e jesuítas, por exemplo), não se trata, evidentemente, de uma recepção linear (e qual é?), já que, segundo o testemunho de um destes leitores, o ex-frade dominicano Ivo do Amaral Lesbaupin, “muitas vezes lia-se essa obra 'pulando' as seções críticas para estudar apenas a exposição - notável - do pensamento marxiano" (apud Löwy, 2000, p. 244).

Por sua vez, já nos referimos à grande influência exercida pelos escritos do pe. Vaz não apenas no âmbito dos movimentos estudantis da Ação Católica mas sobre "toda [uma] geração" (Kadt, 2003, p. 111). Um excelente exemplo disso é o lugar ocupado por suas concepções de "ideal histórico" e "consciência histórica" nos intensos debates promovidos nas décadas de 1950 e 1960 tanto pela JUC e pela Juventude Estudantil Católica (JEC) quanto pela própria União Nacional dos Estudantes (UNE), a ponto de ser saudado por Herbert José de Souza, o Betinho (1962, p. 9), um dos mais proeminentes dirigentes destes movimentos, como "o filósofo em cujo pensamento procuram, os novos, os rumos de uma reflexão séria”. Assim, não deixa de causar espanto a acusação de "culturalista alienado" que o mesmo Vaz sofrerá no final da década de 1970 entre os agentes da pastoral popular.

\section{Um assunto quente}

Está mais do que na hora de retornar aos companheiros reunidos em 1978. Já expusemos o estado das artes do pensamento social jesuítico no que tange 
à interpretação de Marx. Vamos ver como tal debate repercutia nas costas brasileiras. Para começar esse levantamento, uma pergunta se coloca: como se inseria o marxismo na formação filosófica de então? Uma excelente crítica do obscurantismo da Companhia de Jesus (no Brasil, pelo menos), nos anos 1940, é-nos oferecida pelo padre Fernando Bastos de Ávila (2005). Do ponto de vista teórico, ele a resume como uma "má escolástica"; na dimensão psicológicoafetiva, um "campo de concentração espiritual". A formação filosófica, por exemplo, era feita com base no livro de Historia da filosofia do padre Leonel Franca, um dos jesuítas mais respeitados do Brasil na primeira metade do século passado, doutor em Filosofia e Teologia pela PUG e fundador e primeiro reitor da PUC do Rio de Janeiro, em 1940. No entanto, nas mais de 300 páginas de seu manual, um "texto modesto" (nas palavras elegantes de Ávila) lançado em 1918, é pouco o que se consegue aprender a respeito de Marx: as datas de nascimento e morte, que ele se inspirou no idealismo hegeliano "para desenvolver o seu materialismo histórico e o seu sistema de socialismo" e que, "com seu socialismo coletivista, errou caminho pretendendo resolver a questão social, politicamente, em nome do interesse" (Franca, 1921, p. 157; 264). ${ }^{19}$ Em suma: condenação sem direito de defesa.

O percurso até o marxismo se dava, no mais das vezes, por atalhos, sobretudo através do personalismo de Mounier. Falando de sua formação entre 1943-1945, feita ainda no Brasil, pe. Vaz lembra da apologética antimarxista da época, expressa nos Cahiers des Archives de Philosophie sobre "la philosophie du communisme". E confessaria, muito mais tarde: "Li muito Marx, nessa época. Procurei lê-lo honestamente, mas devo reconhecer que o li sempre à luz de Hegel, pois o marxismo nunca passou, a meus olhos, de uma província do hegelianismo em permanente estado de revolta" (Vaz, 1976a). De todo modo, até o final dos anos 1950, antes, portanto, do golpe de 1964, quando Vaz colaborava intensamente com a JUC e a AP, predominou a atitude crítica e apologética em face do marxismo, sustentada na tradição do ensinamento social da Igreja e na síntese filosófico-teológica neoescolástica ("escolástica" num sentido amplo). Com a aproximação crescente entre os militantes da Ação Católica, em cuja orientação inicial predominava o humanismo cristão, e as organizações de esquerda (no

\footnotetext{
${ }^{19}$ Nem todos os pensadores receberam o mesmo tratamento: um contemporâneo de Marx, Herbert Spencer, por exemplo, mereceu cinco páginas de exposição, crítica e condenação, ou seja, bem mais que as cinco linhas dedicadas ao teórico comunista.
} 
meio estudantil, nos sindicatos rurais e, em menor grau, na classe operária), ao longo da segunda metade dos anos 1960 e, especialmente, na década de 1970, tal postura seria "infinitamente mais difícil", comenta o filósofo, na medida em que ela haveria de ceder lugar a "uma atitude não apenas de simpatia como de adesão e utilização acrítica". ${ }^{20}$

No Brasil, o pe. Lima Vaz irá desempenhar um papel de destaque nesse debate através da categoria de "consciência histórica", na tentativa de oferecer uma leitura cristã da história. As obras que marcam esse período, Cristianismo e consciência histórica (1963) e Ontologia e história (1968), visavam apresentar a consciência cristã como consciência histórica e servir de guia para a comunidade cristã. A primeira, apesar de não muito extensa, exerceu uma grande influência na formação de toda uma geração de militantes cristãos, sobretudo os jucistas. Sua formulação explicitamente "progressista" por certo que contribuiu para isso:

Pensamos poder mostrar que a edificação da imagem moderna do mundo, na forma do universo científico, (...) vai ao encontro no plano das significações profundas da visão cristã. (...) A visão cristã do mundo define para o homem cristão uma forma original de "consciência histórica", (...) que nos permite descobrir as exigências autênticas de realização humana dos homens de uma determinada época ou cultura e situar as opções concretas desses homens na linha de tais exigências (Vaz, 1963, p. 5; 61, grifos no original).

Na segunda, que reúne dez artigos publicados ao longo da década anterior, Vaz se situa numa "filosofia da práxis", preocupada com o concreto, a ação, o destino do homem na história e o sentido coletivo da dimensão temporal, tudo isso através de um método dialético ortodoxamente tomista, que "não cede nem ao hegelianismo, nem ao materialismo dialético" (Villaça, 1975, p. 184) ${ }^{21}$ Seu próprio autor não esconde a intenção de assegurar "uma atitude permanentemente crítica em face do marxismo na sua interpretação do sentido

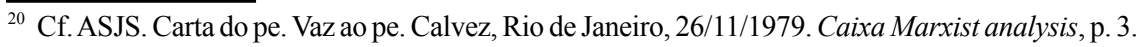

${ }^{21}$ De fato, Villaça reputa o pe. Vaz como "o mais profundo tomista do Brasil contemporâneo", no que reforça o vaticínio feito anos antes por Fernando Arruda Campos (1968, p. 144): “A obra de Henrique Vaz é, entre nós, segundo julgamos, a mais bem sucedida tentativa de repensamento da filosofia do Angélico dentro do contexto em que se coloca a problemática no pensamento filosófico moderno e atual". Por fim, numa crítica recente, Marcelo Perine (2006, p. 9) destaca em Vaz a "rigorosa formação escolástica e a fecunda apropriação dos elementos da filosofia moderna e contemporânea". 
da história" (Vaz, 1986, p. 294). Sem dúvida, na década que antecedeu ao evento de Medellín, a utilização da algumas categorias básicas da teoria marxista da história e da sociedade de classes passou a predominar na expressão conceitual daqueles militantes cristãos. O influente filósofo reagiu a isso numa série de artigos publicados em Síntese. Intitulados "Marxismo e filosofia" e divididos em três partes, saíram nas primeiras edições da revista, ao longo de 1959. Neles, Vaz efetua um balanço do marxismo como filosofia, pondo em questão sua validade teórica e chegando a conclusões surpreendentes.

Uma ideia-força serve de fio condutor para toda a argumentação: sem ter se dado nunca conta disso, Marx havia se comprometido em demasia com Hegel e é esta matriz hegeliana, incrustada no seio do projeto marxista, a responsável pela "irremediável", "insuperável" e "invencível" contradição entre materialismo e dialética (os adjetivos são todos do filósofo mineiro), por conta da impossibilidade lógica de um materialismo que fosse ao mesmo tempo histórico e dialético. Um autêntico diálogo de "irmãos inimigos", diz Vaz (1959c, p. 47). Por outro lado, dessa mesma obra, sobremaneira no terceiro dos Manuscritos econômico-filosóficos de 1844, que trata da propriedade privada e do comunismo, emerge a elaboração mais vigorosa da unidade homem-natureza "na qual se exprime o sentido mais profundo do seu humanismo" (ibidem, p. 54). Mas um humanismo naturalista, cuja contraface é o ateísmo, já que qualquer abertura para a transcendência contradiz suas bases teóricas.

Precisamente aí residiria o núcleo da contradição, de acordo com o pe. Vaz, na medida em que Marx elevou o processo histórico à categoria de "absoluto" e "exterior" à consciência. Esta se viu, por definição, relegada a um "momento" deste processo total, unicamente o "ser consciente", nele imanente e condicionada por ele. Todavia, é esta mesma consciência que, num momento dado, deve adequar-se à totalidade da história para pronunciar-se sobre a significação total e absoluta do seu processo, ou seja, de imanente e condicionado o sujeito transmuta-se naquele que afirma o processo histórico como tal, sendo-lhe, portanto, transcendente. Estaríamos, dessa forma, diante do dualismo entre um processo dialético como totalidade absoluta e um processo histórico como contingência. E também a consciência revolucionária seria atravessada por este dualismo contraditório, o que a lançaria no terreno da fabulação mítica. Eis, então, que surge mais um confessor do ateu alemão, disposto a descobrir no mais íntimo do pensamento de Marx (melhor dizendo, no seu espírito) "a exigência inelutável de uma opção mística - de uma mística transtornada - que pesará 
decisivamente no seu prodigioso destino histórico" (Vaz, 1959b, p. 31-32). A conversão do "ateu positivo" em "santo cristão" deve ter trazido uma significativa abertura no horizonte de ação para a legião de leitores militantes do pe. Vaz:

O ato de fé ao reverso é o início de uma ascensão mítica, e sua coroa é um ato de "puro" amor, a entrega desinteressada ao "sentido da História" no advento da sociedade comunista. Trata-se de um empenho tipicamente religioso. (...) Se o ateu positivo chega a um estado de "puro amor", de união mística com a História, e traz consigo, desfigurada e transtornada, a força criadora do dom de si, só um tipo se lhe opõe eficazmente: o santo cristão. (...) Apresentar, assim, o apelo à santidade cristã no termo de uma longa meditação sobre o marxismo não é, a nosso ver, projetar um ideal abstrato num futuro utópico. É voltar nossas esperanças para as energias espirituais do mundo cristão que tendem a uma realização mais perfeita do Evangelho (1959d, p. 65-68).

Seu companheiro de formação, Ávila (2005, p. 358) não tem dúvida de que "foi o pe. Vaz, com seus primeiros estudos sobre cristianismo e marxismo, sobre a consciência histórica, que despertou a Igreja do Brasil e da América Latina de sua piedosa hibernação devocional”. Em apoio a esta opinião, é sempre bom recordar a atitude da maioria do episcopado brasileiro na crise que redundaria na ditadura militar. Em julho de 1962, diante da grave situação nacional, a Comissão Central da CNBB divulgou um documento no qual se mostrava angustiada com a ordem capitalista, mas condenava igualmente as "soluções marxistas, não menos desumanizantes, pois atentam contra os direitos fundamentais da pessoa". ${ }^{22}$ Dois meses após o golpe, a mesma Comissão Central se reuniu no Rio de Janeiro para pronunciar-se sobre aquela "situação nacional", agradecendo aos militares pelo "êxito incruento de uma revolução armada" (se soubessem quanto sangue haveria de correr...) e rendendo graças a Deus, "que atendeu às orações de milhões de brasileiros e nos livrou do perigo comunista". ${ }^{23}$

Apesar de ausente naquele Encontro sobre Fé e Marxismo, já que jamais fez parte do PaPo, o padre Ávila era, no entanto, uma presença intelectual significativa. A essa altura do nosso estudo, sua pessoa dispensa maiores apresentações. Conhecemos algumas passagens decisivas de sua vida, vamos

${ }^{22}$ CNBB. A Comissão Central da CNBB à nação brasileira, 14/07/1962 (apud Beozzo, 1993, p. 67).

${ }^{23}$ Comissão Central da CNBB. Declaração da CNBB sobre a situação nacional. Rio de Janeiro, 2/07/1964 (apud Lima, 1979, p. 147). 
aprofundar um pouco mais seu pensamento, sobretudo no que diz respeito às ideias de esquerda. Por conta da formação deficiente e pouco permeável aos "ventos da modernidade", ele próprio confessa que "conhecia muito pouco" de Marx até 1945 (isso depois dos três anos de Filosofia...), quando viajou para a Europa a fim de iniciar os estudos de Teologia e fazer seu doutorado. Sua opção antissocialista, porém, antecede o próprio contato com a obra marxista. E se cristalizará na medida em que sua formação se robusteça. De volta ao Brasil e já doutor em Ciências Políticas e Sociais, Ávila (2005, p. 249-250) não se contentará em lecionar em diversos cursos da PUC, fundando, em 1957, a Escola de Sociologia e Política "com uma orientação mais aberta e mais voltada para a realidade brasileira", como forma de contrapor-se à influência do marxismo, como narra em suas memórias.

É a partir desta escola e da revista Síntese, criada também por ele dois anos depois, que Ávila exporá suas concepções acerca do socialismo e do marxismo. Já mencionamos, aliás, duas obras nas quais ele fez isso: Neocapitalismo, socialismo, solidarismo, de $1963,{ }^{24}$ e Pensamento social cristão-Antes de Marx, de 1972. Esta última tem um interesse mais "arqueológico", de modo que nos concentraremos no livreto dos anos 1960, cuja influência se espraiou pela juventude democrata cristã da época, gente da estirpe de Franco Montoro, José Richa e Afonso Camargo, e pela Associação de Dirigentes Cristãos de Empresa (ADCE), igualmente inventada por Ávila. O livro abre com o Manifesto Solidarista:

O solidarismo é uma doutrina, portadora de uma dinâmica tendente a projetálo em um movimento e a encarná-lo em um sistema. (...) A comunidade é a grande descoberta e a grande força do Solidarismo. (...) O Solidarismo não se constitui de negações, de anátemas. Sua essência não é ser anticapitalista ou anticomunista. (...) Ele é personalista e comunitário. (...) O Solidarismo é o ideal a que confusa e inconscientemente aspiram todos aqueles que anseiam por um Brasil realmente democrático e cristão (Ávila, 1963, p. 9-13, grifos no original).

Como reza o Manifesto em sua primeira frase, estamos diante de uma doutrina. E é menos como professor de Sociologia e mais como doutrinador que Ávila vai expondo os principais fundamentos do solidarismo, apresentado como

\footnotetext{
${ }^{24}$ O livro seria reeditado mais duas vezes: como Solidarismo, em 1965, pela mesma editora Agir, numa edição revista, e com o título ampliado (e modernizado) para Solidarismo. Alternativa para a globalização, em 1997, pela Santuário, de Aparecida (SP).
} 
a alternativa mais adequada para "um Brasil realmente democrático e cristão". As duas outras estão enunciadas no título do opúsculo, Neocapitalismo e socialismo, já que o capitalismo enquanto tal "está liquidado, e só um romantismo nostálgico pode ainda sonhar numa volta às suas formas puras" (idem, p. 17). Antes, porém, que se imagine estarmos diante de mais uma proposta de terceira via, há que alertar para o fato de que o Manifesto elege dois inimigos, mas estes não são o neocapitalismo e o socialismo e sim o socialismo e o comunismo. Assim, para afastar qualquer suposição de anticapitalismo, Ávila (ibidem, p. 39-40) se apressa em esclarecer que

não se pode dizer que a Igreja condene o neocapitalismo. Ela não poderia condenar um conjunto de medidas sociais e econômicas que representam um incontestável progresso sobre a situação histórica anterior. (...) Não podia condená-lo como sistema uma vez que, enfim, ele funciona bem, satisfazendo às exigências de justiça social em muitos países do mundo, por exemplo, nos Estados Unidos, na Alemanha Ocidental e em outros. É certo que ele ainda atribui uma supremacia ao capital. Contudo, desde que ele se funde num direito de propriedade de bens produtivos justamente adquiridos e desde que ele se exerça segundo as exigências do bem-comum, não vemos que seja intrinsecamente condenável.

Quanto ao socialismo, além de considerá-lo "essencialmente um sistema totalitário", deixa bem clara a finalidade do Manifesto ao anunciar o solidarismo como "a única opção realista capaz de superar nossa fase de subdesenvolvimento e de nos preservar da sedução do socialismo" (ibidem, p. 20; 25). Mas não iremos detalhar agora esta concepção de socialismo. É a lição sobre o materialismo histórico e dialético que desejamos ouvir dele:

O único princípio válido para o comunista é que o fim justifica os meios. (...) Para um comunista, a violência, a mentira, a calúnia, a traição, são moralmente bons, desde que sirvam ao fim que almejam: a conquista do poder. Daí a dificuldade de diálogo com o comunista. Rigorosamente falando, nunca se pode saber se ele é sincero, ou se apenas simula sinceridade para cumprir ordens do partido. $\mathrm{O}$ materialismo dialético não é apenas inaceitável para um cristão. É inaceitável por qualquer pessoa que repudia uma interpretação absurda e incoerente do mundo e da história. (...) Daí se segue que um católico não pode ser comunista e, se entra no partido comunista, é excluído da comunhão católica, isto é, não pode participar dos sacramentos da Igreja (ibidem, p. 72-73; 80). 
O confessor dá lugar ao inquisidor. E ao político que não se furta em clarificar de que lado está: a revista Síntese era apoiada pelo Instituto de Pesquisas e Estudos Sociais (Ipes), o qual, por sua vez, era mantido por setores importantes do empresariado nacional, trabalhando em íntima colaboração com a Agência Central de Inteligência (CIA) e a Embaixada norte-americanas. Nestes primeiros anos da década de 1960, o Ipes financiou uma rede de entidades de defesa da "democracia e da livre-iniciativa", como o Instituto Brasileiro de Ação Democrática (Ibad), patrocinando a desestabilização do governo de João Goulart (cf. Beozzo, 1993, p. 49).

\section{Ad majorem Marx scientiam}

Outro jesuíta que viu Cavazzuti e Vaz se enfrentarem em 1978 foi o pe. Manuel Andrés Mato (mais conhecido como pe. Andrés). Mas não podemos considerá-lo simples assistência, já que também ele fizera uma leitura minuciosa do marxismo. Em sua tese de Doutorado em Filosofia, defendida na PUG em 1969, Andrés, então no Ibrades, se propõe a analisar a concepção de homem na obra de Karl Marx (mais especificamente nos Manuscritos econômico-filosóficos) e no materialismo dialético soviético de então, isto é, a União Soviética pós-Stalin. Dividida a obra rigorosamente em duas partes, ele dedicará as últimas páginas para proceder a uma síntese final do material compulsado. Cumpre registrar que o trabalho, apesar de escrito em castelhano, traz cerca de $90 \%$ de sua bibliografia em russo, com autores que vão de Antonov a Tugarinov, o que dá uma boa dica de quem lia as edições do Pravda entregues na rua Bambina, em Botafogo, no Rio de Janeiro. Na primeira parte, publicada em 1968, sob a forma de artigo, numa revista dos jesuítas espanhóis, Andrés disseca a obra de juventude de Marx decidido a (1) precisar o humanismo que dela se depreende e (2) demonstrar sua conexão com o socialismo. De acordo com ele, trata-se de um humanismo que coincide com o ateísmo socialista mas não com o ateísmo filosófico, justamente porque Marx rejeitara o ateísmo como base do seu humanismo. Entretanto, pondera o jesuíta espanhol, ao definir o homem por sua identidade dialética com a realidade total, "da qual deve distinguir-se afirmando-se", produz tão-somente uma crítica negativa, evitando cair num reducionismo materialista ou idealista, sem dotá-la, porém, de uma fundamentação positiva (cf. Andrés Mato, 1969, p. 54). 
Seguindo os passos de Chambre, Andrés mergulha nas profundidades do marxismo na União Soviética. ${ }^{25}$ Neste, o humanismo de Marx se converte em humanismos, já que o materialismo dialético, disposto a expurgar qualquer vestígio de "antropologismo", considera que os Manuscritos, encharcados de um humanismo ideal por conta da influência ainda fresca de Hegel, não representam o marxismo genuíno, este, sim, marcado pelo humanismo real. Ingressando em sua síntese final, Andrés conclui que as reflexões do materialismo dialético soviético são inconciliáveis com o pensamento marxista da década de 1840 . E, mais que isso, ao se embasarem na dialética da natureza, terminam por enredar-se numa contradição insolúvel: ou a subjetividade é tida como algo real, numa formulação idealista, ou se torna mera sombra da matéria, na concepção materialista vulgar (ibidem, p. 161). Sua tese é inconclusiva (algo inusual nestes estudos), como a sugerir que a superação deste dualismo talvez não fosse possível senão no plano da ação histórica concreta.

Mas qual interpretação de Marx desenvolveu Cavazzuti naqueles dias? Não dispomos de apontamentos de suas intervenções, mas podemos inferi-la de sua tese de Doutorado em Filosofia, igualmente defendida na universidade romana da Companhia, em 1971. Versando sobre a clássica relação entre o marxismo e o humanismo, introduzia a novidade de discutir os fundamentos teóricos da antropologia marxista a partir do estruturalismo. Filiando-se à proposta althusseriana da "cesura epistemológica", Cavazzuti considera que, no Marx da maturidade, a necessidade da história não será mais fundada sobre uma ideologia humanista, o que recoloca a pergunta fundamental: até que ponto o marxismo pode ser aceito por um cristão? No entanto, Cavazzuti não é um althusseriano plenamente convertido: enquanto, para o filósofo francês, a teoria científica de Marx demonstrou-lhe a inconsistência e a natureza ideológica de todo humanismo, no que ele denominava de um "anti-humanismo teórico", Cavazzuti (1977, p. 36) continua achando que "Marx não abandona completamente sua filosofia humanista. É inevitável que ele continue a ter uma concepção do homem e do universo e, portanto, uma visão ideológica da realidade". O jesuíta procura fugir desta contradição, alegando que, ainda que presente, tal visão perdeu seu status explicativo da história real dos homens. Somente no final ele explicita para

\footnotetext{
${ }^{25}$ Curiosamente, não consta da bibliografia de Andrés o livro de Chambre sobre o marxismo na União Soviética. Aliás, daquela tetralogia marxiana da Companhia de Jesus dos anos 1950, consta apenas os livros de Wetter, Der dialektische Materialismus, edição de 1958, e de Calvez, La pensée de Karl Marx, em sua $1^{\text {a }}$ edição.
} 
quem se orientava sua reflexão, sugerindo uma operação de "desideologização" das posições contrapostas (cristã e marxista). Sua preocupação, pois, se refere àquele atribulado diálogo que temos acompanhado:

É necessário que os cristãos, por exemplo, purifiquem sua fé de toda sedimentação ideológica. E, de outro lado, é indispensável que os marxistas se perguntem até que ponto sua visão da realidade é científica e não pré-formada. (...) Querendo ser realmente científico, o marxismo deve renunciar a definir a essência mais profunda do homem e do mundo, sua destinação e seu fim último (Cavazzuti, 1977, p. 75-76).

Em resumo, Cavazzuti vê na interpretação do marxismo defendida por Althusser uma abertura de perspectivas no diálogo entre cristãos e marxistas, na medida em que dissocia o "socialismo científico" da "filosofia materialista". E, bem ao contrário da tradição inaugurada nos anos 1940, não se consome em "surpreender" o inconsciente religioso recalcado no judeu Marx, mas definir uma plataforma comum a partir da qual marxistas e cristãos pudessem bater um papo, sabedores de suas profundas diferenças e das efetivas possibilidades de acordo e ação conjunta. ${ }^{26}$

Outro ausente em corpo mas não em espírito naqueles dias agitados foi o pe. Pedro Dalle Nogare. Um dos fundadores do Ceas baiano, o pe. Pedro pertencia à Província Vêneto-Milanesa, da qual foi provincial nos anos 1950, antes de vir para o Brasil. Também doutor em Filosofia pela PUG e pela Universidade de Gênova, elaborou sua obra mais divulgada a partir das aulas de Filosofia ministradas na Universidade Federal da Bahia (UFBA) e na Ucsal. Trata-se de um sucesso editorial, tendo chegado à $13^{\mathrm{a}}$ edição. Publicada originalmente em 1973, tem o estilo de seu autor: direto, sem falsas erudições nem meias palavras. Não gasta muita tinta para afirmar que o marxismo tradicional (isto é, de Marx) é "uma doutrina humanista, embora de um humanismo mutilado. Mas o marxismo como praxe, regime político, sempre se mostrou anti-humano" (Dalle Nogare, 1985, p. 102).

Ele também analisa os outros marxismos, nos quais se revela sua face antihumanista. Refere-se especificamente a Louis Althusser, para quem seria cair em flagrante contradição falar de um humanismo marxista ou socialista, já que

\footnotetext{
${ }^{26}$ A tese de Cavazzuti pode ser consultada também através da série de artigos (citados nas Referências bibliográficas) que ele publicou na Revista de Cultura Vozes, o que reforça a larga circulação de suas ideias.
} 
o socialismo seria um conceito científico, enquanto o humanismo estaria na esfera ideológica. Considera que Althusser sustenta "a tese escandalosa do antihumanismo teórico de Marx" (idem, p. 109). Neste aspecto, Dalle Nogare filia-se à formulação de Calvez, numa aberta discordância com Cavazzuti e os demais intérpretes humanistas do marxismo que propõem uma cesura epistemológica, até mesmo uma ruptura radical, entre o Marx jovem e o Marx adulto. No seu entendimento, haveria simplesmente uma "mudança de perspectiva, motivada exatamente pelas reflexões filosóficas de Marx jovem. (...) Bem longe de significar ruptura ou descontinuidade: há continuidade e até causalidade. Ousaríamos até afirmar que se Marx não houvesse passado pela experiência dos Manuscritos econômico-filosóficos de 1844 não se teria orientado para os estudos de economia, porque lhe teriam faltado motivação e impulso" (ibidem, p. 113-114).

Num artigo posterior às primeiras edições de seu livro (e estranhamente não incorporado a ele), Dalle Nogare voltaria ao "debate empolgante" em torno do humanismo cristão versus o humanismo marxista. E, apesar de ratificar a tese da continuidade entre o Marx da juventude e da maturidade, atenua sua postura, defendendo que, mesmo em se admitindo a procedência de um corte epistemológico, ainda assim isso não autorizaria falar em anti-humanismo, muito pelo contrário. Ao abandonar um humanismo meramente teórico por um outro, teórico-prático, Marx se tornaria "num certo sentido mais humanista que antes". O anátema aos regimes nascidos desta inspiração teórica, contudo, são ampliados. O episódio da invasão do Afeganistão pela União Soviética, em 1979, seria apenas mais uma confirmação de uma doutrina humanista que se torna desumana e opressiva quando transposta para a prática. O professor de Antropologia faz questão de frisar que este anti-humanismo da práxis marxista não decorreria da "aplicação da genuína doutrina" mas de um flagrante desvio, cuja causa é identificada na "supervalorização do partido nos regimes comunistas, supervalorização introduzida por Lênin” (Dalle Nogare, 1981, p. 62). ${ }^{27}$

Não é acidental o volume e a densidade da reflexão sobre o marxismo por parte dos padres do Ceas, fossem ou não integrantes do PaPo. O pe. Vaz sinalizava isso quando se contrapunha à visão dos "membros do Ceas de Salvador". $\mathrm{O}$ artigo que abriu esta leitura marxiana da entidade baiana - pouco pretensioso, não era mais que "notas para uma releitura" de um artigo de Nell-Breuning - foi

${ }^{27}$ Como se vê, Dalle Nogare não segue Calvez inteiramente, ao dissociar a doutrina marxista de sua concretização histórica. 
elaborado em 1970 pela equipe editorial dos Cadernos do Ceas em coautoria com o pe. Andrés (1970, p. 12-18), em seus derradeiros momentos no Ibrades. ${ }^{28}$ A presença de Marx nos Cadernos foi irregular até a Anistia, em 1979, quando teve início um verdadeiro boom do alemão: entre os números 64 (de novembro/ dezembro de 1979) e 100 (de novembro/dezembro de 1985) quase não há edição que não o traga de modo explícito, através de textos originais ou traduções. A revista publicou uma elucidativa "exposição de motivos" a esse respeito:

A nossa revista, ao publicar textos dos ou sobre os clássicos do marxismo, não tem apenas um interesse teórico, mas tem sobretudo uma preocupação prática. Eles interessam pelo fato de conterem ideias que, entre outras, concorrem a definir a orientação e os instrumentos de luta do movimento popular. Também porque nascem de uma preocupação que nos é comum: não tanto a de conhecer a verdade da história e da sociedade, mas a de transformar a realidade para que se torne mais humana. (...) Para que o pensamento de Marx possa ser compreendido corretamente e possa oferecer ensinamentos úteis nas lutas do movimento popular, é necessário que cada escrito dele seja lido à luz das experiências assimiladas pelo autor e, por fim, à luz das particularidades da luta ou da polêmica que o inspiraram (Ceas, 1982, p. 57, grifos nossos).

Se quisessem ser eruditos, os editores dos Cadernos poderiam ter adaptado a fórmula inaciana Ad majorem Dei gloriam [Para a maior glória de Deus] ao contexto do capitalismo do século XX: Ad majorem Marx scientiam [Para o maior conhecimento de Marx]. Seu esforço de compreensão do marxismo partia da necessidade de não se separar a teoria da práxis, nem fazer dos clássicos um dogma, um "texto sagrado", "mas um ponto de referência teórico válido na medida em que pode trazer luz sobre a prática atual do movimento popular" (Ceas, 1982, p. 58). Num encontro do PaPo do Nordeste, realizado em João Pessoa na mesma época desta tomada de posição, pe. Cláudio Perani, ${ }^{29}$ outro dos presentes ao acalorado debate de 1978, esboça um rápido

\footnotetext{
${ }^{28}$ Com menos de 20 páginas, essa edição tem um valor histórico por marcar a estreia de Andrés no Ceas, ele que é seu atual decano, com mais de 25 anos de compromisso com as classes populares...

${ }^{29}$ Oriundo da Província Vêneta, o bergamasco Perani chegou à Bahia como escolástico em 1962 e se ordenou dois anos depois. A partir de 1967, junto com outros jesuítas, leigos e leigas, ajudou a fundar e consolidar o Ceas baiano, onde trabalhou até 1995, quando foi transferido para Manaus. Lá, criou e dirigiu por alguns anos o Serviço de Ação, Reflexão e Educação Social (Sares), até a sua morte, em 8/08/2008. Para uma breve reflexão em torno da contribuição de Perani na caminhada da Igreja progressista brasileira, cf. Costa (2008).
} 
histórico da assessoria do Ceas em quatro etapas, a saber: 1) cursos sobre a problemática do desenvolvimento para intelectuais de nível universitário; 2) cursos com agentes de trabalho social popular (da cidade e do campo) sobre a realidade socioeconômica; 3 ) cursos e seminários locais com agentes de pastoral e animadores e 4) visitas e acompanhamento de práticas locais (CEBs, movimentos, grupos de trabalhadores, associações, oposições sindicais etc.). Ressaltando que, àquela altura, o Ceas se encontrava nas duas últimas fases, Perani (1982, p. 4) identifica "os mestres" dessa caminhada: "o povo, com sua consciência, visão política, resistência e luta, sua fé. E os leigos, também de orientação marxista, por sua visão mais concreta e científica".

Com relação a essa contribuição científica da teoria marxista, Perani faz questão de explicitar que "trata-se de considerar os elementos fundamentais de uma sociedade, isto é, aqueles que, em grandes traços, caracterizam uma formação social e determinam em grande parte o seu funcionamento: os elementos estruturais" (idem, p. 5, grifos no original). É verdade que este fenômeno não foi exclusivo do Cias baiano, tendo ocorrido (em perspectivas e graus variados, evidentemente) em diversos outros centros de reflexão implantados pelos jesuítas latino-americanos desde o final dos anos 1950. Suas publicações são um excelente termômetro disso. Além disso, seu impacto ultrapassou o círculo eclesiástico (ainda que tenham cumprido aí um papel notável de divulgação de certo pensamento de esquerda), atingindo uma parcela considerável da intelectualidade acadêmica e de setores de esquerda, que encontravam nelas um canal de interlocução: Síntese foi na sua origem um projeto editorial da PUC-Rio, enquanto os Cadernos gozavam de ampla circulação, tendo alcançado, nos anos 1980, a cifra de quatro mil assinantes espalhados pelo Brasil e outros países.

Há, contudo, que fazer uma diferenciação entre o Cias do centro (o Ibrades) e o nordestino (o Ceas), já que, neste último, a aproximação entre o cristianismo e o marxismo não se circunscrevia ao plano da teoria, mas envolvia as relações pessoais: o diálogo não era apenas com o marxismo mas, sobretudo, com os marxistas. Naquele ano-chave de 1979, os jesuítas do Ceas destacavam a importância dos leigos (e, dentre eles, os marxistas) na opção por uma prática mais concreta e questionadora da ordem estabelecida: "O critério da 'indiferença', que coloca o absoluto somente em Deus, nos ajuda a descobrir a necessidade de reconhecer os condicionamentos ideológicos da nossa fé e da nossa prática. Freud e, sobretudo, Marx podem ajudar como mestres da suspeita para descobrirmos isso. Praticamente, foram os leigos do Ceas que colaboraram para nós 
fazermos essa caminhada". ${ }^{30} \mathrm{O}$ depoimento concedido por Perani (2000, p. 89) anos depois é lapidar:

Devo reconhecer a grande contribuição dos amigos marxistas que, introduzindo-me no campo da análise marxista, me permitiram não somente aprimorar o conhecimento da realidade em que vivemos e o caminho da história, mas também aprofundar minha interpretação do Evangelho e da prática de Jesus, inspiradora da minha prática hoje.

No Ibrades, por sua vez, apesar de também ocorrer este contato direto (seria praticamente impossível evitá-lo), o interesse maior estava na exegese do marxismo. Na ocasião da sua invasão, em 1970, havia inclusive uma grande divergência, entre os generais envolvidos na operação, se o que havia ali era estudo do marxismo ou subversão real. Reflexivo ou subversivo, o certo é que o Ceas, originalmente formado por "um primeiro grupo de Jesuítas que, aprofundando a Doutrina Social da Igreja, trabalhassem na pesquisa social e no processo de transformação da mentalidade predominante (burguesa e capitalista) num sentir, pensar e, consequentemente, agir, mais de acordo com tal Doutrina" (Cueto, 2002), interpretou essa doutrina segundo parâmetros nem sempre condizentes com o magistério oficial. Sua caminhada pelas sendas do marxismo não foi, por conseguinte, isenta de percalços. Como era de se esperar, tal postura criou atritos com a hierarquia eclesiástica. Apenas como ilustração das tensões vivenciadas nestes tempos iniciais, vale a pena citar a carta que o arcebispo dom Avelar Brandão Vilela enviou à entidade em 1972 sobre os pontos a serem "examinados e reexaminados" no trabalho então realizado:

4) O aproveitamento da análise científica dos fatos caracterizada por uma ideologia não cristã pode trazer muitos equívocos, sobretudo quando se quer fazer trabalho de base; 5) Estou pessoalmente convencido que o Padre Geral não ouviria bem a afirmação de que o CEAS não aceita a orientação oficial da Igreja. ${ }^{31}$

Diante da insinuação de que os jesuítas baianos estariam descumprindo seu quarto voto (o de fidelidade especial ao papa), Cláudio Perani, então coordenador do Ceas, em correspondência datada do mesmo dia, responde que "não

\footnotetext{
${ }^{30}$ Ceas Salvador (Encontro SJ). Campo, Salvador, mai. 1979, p. 4, grifo no original.

${ }^{31}$ Carta de dom Avelar Brandão cardeal Vilela ao pe. Cláudio Perani. Campo. Salvador, 29/10/1972.
} 
é intenção do Ceas não aceitar a orientação oficial da Igreja, apenas Tomás [Cavazzuti] queria referir-se àquela liberdade crítica afirmada na Octogesima Adveniens". A verdade é que as "opções teóricas concretas" amadureciam tanto através da reflexão individual, a partir dos Cias ou num ciclo de debates específico dos membros do PaPo. Respondendo à convocatória dirigida a todos os jesuítas pelo p. geral, um grupo de trinta jesuítas dos Cias latino-americanos reuniu-se em São Miguel (Argentina) em 1974 para refletir sobre a realidade do continente, os instrumentos científicos mais adequados para seu entendimento e a função da teologia no ordenamento da ação pastoral. Concluído o encontro, remetem aos provinciais e demais delegados à Congregação Geral XXXII, que seria inaugurada no final daquele ano, uma série de considerações, na intenção de contribuir para uma melhor percepção "dos problemas específicos do nosso continente que não são de fácil compreensão segundo a ótica dos países desenvolvidos". ${ }^{32}$ Vejamos como os padres latino-americanos encaram a utilização do marxismo: "Reivindicamos a necessidade de uma orientação das ciências sociais que permita, também com a ajuda da teoria e da metodologia marxista, uma crítica da ideologia dominante pela qual se mascara, ao povo, sua própria situação de opressão, e se impede todo processo que conduza a sua autêntica libertação" (idem). Num Encontro Nacional do PaPo realizado anos depois na ilha de Itaparica, na Bahia de Todos os Santos, foram fixados os critérios e orientações gerais para a vitalização da dimensão social da Companhia de Jesus no Brasil. Vejamos as mais contundentes:

1.1. Que façamos uma opção de solidariedade com os oprimidos, pois, apesar da nossa boa vontade, estamos com os nossos Colégios e Universidades necessariamente mais ligados aos opressores, à burguesia (...); 1.2. Que os nossos trabalhos e a nossa presença sejam com grupos que representam uma força maior na luta por uma verdadeira mudança das estruturas (...); 1.5. Que o próprio Provincial seja uma pessoa comprometida com o social. E que o ecônomo não seja "comprometido" com uma visão capitalista do mundo; 1.6. Formação: a) Que haja, para todos os escolásticos, um estudo sério e positivo do marxismo, segundo as normas da Congregação dos Seminários; b) Que as casas de formação se situem em bairros populares, porque deixar as nossas casas em ambiente social de alta classe prejudica qualquer engajamento com os operários (...); 1.7. Que se possibilite,

32 A los PP. Provinciales y Delegados a la Congregación General, de Latinoamerica. Campo. São Miguel, jul. 1974, p. 1, tradução minha. 
para todos os jesuítas, uma reciclagem que comportaria um estudo aprofundado do marxismo numa abordagem das ciências humanas (...); 1.9. Que as Províncias deem um apoio maior aos centros de reflexão e pesquisa (Ceas, Cedope, Ibrades), para que estes possam colaborar eficazmente com os trabalhos de base; (...) 2.5. Insistir para que todas as casas registrem os seus funcionários e empregados, como é Lei, e que se generalize a praxe, já adotada por diversas casas, de pagar o justo salário e não só o mínimo (...); 3.6. Que, no período de formação, se ofereçam possibilidades de ter experiências no mundo operário. 3.6.1. No Noviciado, por exemplo, seja colocada uma experiência de vida operária, como trabalho direto por alguns meses (...). 3.6.2. No Magistério, não se ofereça só a experiência dos Colégios mas também a possibilidade de participar diretamente da vida operária com trabalho em fábrica ou em trabalhos com operários. ${ }^{33}$

Por mais radical que pareça tal programa, não se trata de sonhos de uma noite de verão de jesuítas isolados numa aprazível ilha do litoral baiano (as ilhas às vezes causam reações desse tipo...), antes reflete um certo estado de espírito que se amplia para toda a América Latina, pelo menos. De fato, dois anos depois, os representantes da Pastoral Popular de diversos países do continente reunidos nas cercanias da capital peruana recomendavam aos seus respectivos provinciais, tendo como fonte inspiradora os recém-aprovados documentos de Puebla, que "façam realizar periodicamente uma análise das propriedades de nossas Províncias, de seu emprego de capital, das relações de trabalho de nossas obras, para eliminar delas todo compromisso com qualquer forma de injustiça. Os jesuítas administradores de nossos bens demonstrem seu sentido de justiça e sua carência de espírito capitalista". ${ }^{34}$

No Encontro de Huachipa (Lima, Peru), de junho de 1979, cerca de trinta jesuítas da Pastoral Popular de diversos países de América Latina propunham aos provinciais do continente que "fomentem um estudo sério da possibilidade de utilizar elementos do método de análise marxista enquanto contradistintos da práxis política e da ideologia global marxista. Em especial: a) sua relação com a utopia e a ideologia marxista; b) sua relação com a opção preferencial pelos pobres e com a teologia e c) sua relação com as exigências que se vão dando na

${ }^{33}$ Comissão Nacional do Setor Social (CNAS). Encontro de Mar Grande. Campo. Salvador, 2122 fev. 1977, p. 1-3, grifo no original. Presente em diversas ordens religiosas com esta mesma denominação, cabe ao ecônomo a administração financeira de uma Província.

${ }^{34}$ Propostas aos provinciais da Companhia de Jesus na América Latina a partir dos Documentos de Puebla. Campo. Huachipa, 23/06/1979, p. 6. 
prática dos diversos grupos". E acresciam: "Enquanto se obtêm os resultados do estudo, se propõe que não se proíba o uso desta análise; mais ainda, aproveite-se para verificar se a prática cristã dele contribui para esclarecer o problema que se estuda" (idem, p. 9).

Em relatório elaborado sobre o seminário promovido pela Companhia de Jesus mundial acerca do apostolado social (Roma, junho de 1980), um dos representantes brasileiros, o pe. Martinho Lenz, revelava que um "assunto quente na Companhia hoje também é o uso da análise marxista", sobretudo no contexto latino-americano". Não passara um ano ainda da vitória da Revolução Sandinista na Nicarágua, em julho de 1979, da qual os jesuítas participavam ativamente (ocupando, inclusive, cargos ministeriais), daí porque o p. geral mandou realizar um estudo exaustivo sobre o assunto, encarregando o pe. Calvez (1979) de elaborar o dossiê-síntese de uma enquete respondida por mais de 60 jesuítas especialistas a partir da seguinte questão: "Um cristão pode ou não pode usar o método de análise marxista?". O corpo da Companhia teria que se posicionar...

\section{Referências bibliográficas}

ANDRÉS MATO, Manuel. El hombre en Karl Marx y en el actual materialismo dialéctico. Tese de Doutorado, Filosofia, Pontifícia Universidade Gregoriana, 1969. et al. Notas para uma releitura do artigo de Nell-Breuning em contexto latinoamericano. Cadernos do Ceas. Salvador: Ceas, n. 7, jun. 1970, p. 12-18.

ÁVILA, Fernando Bastos de. Neocapitalismo, socialismo, solidarismo. $2^{\mathrm{a}}$ ed. Rio de Janeiro: Agir, 1963.

.Pequena enciclopedia de moral e civismo. $3^{\mathrm{a}}$ ed. Rio de Janeiro: Fename, 1978. . A alma de um padre: testemunho de uma vida. Bauru: Edusc; Rio de Janeiro: ABL, 2005.

BEOZZO, José Oscar. A Igreja do Brasil: de João XXIII a João Paulo II, de Medellín a Santo Domingo. Petrópolis: Vozes, 1993.

BIGO, Pierre. Marxismo e humanismo: introdução à obra econômica de Karl Marx. Trad. de Ubiratan de Macedo. São Paulo: Herder, 1966.

CALVEZ, Jean-Yves. O pensamento de Karl Marx. 2 volumes. Trad. de Agostinho Veloso. Porto: Tavares Martins, 1959.

(coord.). Consultatio de analisi marxistica. ASJS. Caixa Marxist analysis. Roma: Secretariado de Justiça Social, 1979.

. Marxismo. In: O’NEILL, Charles E. e DOMINGUEZ, Joaquín M. (org.). Diccionario histórico de la Compañía de Jesús. Tomo II. Roma: IHSI; Madri: UPC, 2001, p. 1457-9. 
CAMPOS, Fernando Arruda. Tomismo e neotomismo no Brasil. São Paulo: Grijalbo, 1968.

CAVAZZUTI, Tomás. Marxismo, estruturalismo e humanismo: a antropologia marxista e os fundamentos teóricos do marxismo na controvérsia suscitada por Louis Althusser. Tese de Doutorado, Filosofia, Pontifícia Universidade Gregoriana, 1977a.

. A epistemologia de Louis Althusser. Revista de Cultura Vozes (separata). Petrópolis: Vozes, vol. 71, n. 5, jun.-jul. 1977b, p. 403-413.

. O pensamento científico de Marx. Revista de Cultura Vozes (separata). Petrópolis: Vozes, vol. 71, n. 6, ago. 1977c p. 481-492.

. Uma desideologização do marxismo? Revista de Cultura Vozes (separata). Petrópolis: Vozes, vol. 71, n. 7, set. 1977d, p. 589-596.

CEAS. A teoria e as exigências da prática (introdução). Cadernos do Ceas. Salvador: Ceas, n. 77, jan.-fev. 1982, p. 57.

CHAMBRE, Henri. El marxismo en la Unión Sovietica: ideología e instituciones su evolución desde 1917 a nuestros dias. Trad. de Gonzalez Casanova. Madri: Tecnos, 1960.

. Cristianismo y comunismo. Andorra: Casal i Vall, 1961.

. De Marx a Mao-Tsé Tung: introdução crítica ao marxismo-leninismo. São Paulo: Duas Cidades, 1963.

COSTA, Iraneidson Santos. Que PaPo é esse? Intelectuais religiosos e classes exploradas no Brasil (1974-1985). Tese de Doutorado, História, Universidade Federal da Bahia, 2007.

. As classes populares, mestres da caminhada do padre Cláudio Perani. Cadernos IHU. São Leopoldo: IHU/Unisinos, 2008, p. 1-5.

CUETO, José Manuel Ruiz y Sánchez de. Raizes de uma missão: dados para uma história da Província da Bahia da Companhia de Jesus. Salvador: Província da Bahia, 2002.

CZERNY, Michael. El apostolado social en el siglo XX. Rio de Janeiro: CPAL, s.d. Disponível em: www.cpalsj.org.br. Acesso em: 2/12/2002.

DALLE NOGARE, Pedro. O marxismo é um humanismo? Síntese Política, Econômica e Social - Nova fase. Rio de Janeiro: Cias João XXIII, n. 23, set.-dez. 1981, p. 62.

. Humanismos e anti-humanismos: introdução à antropologia filosófica. $10^{\mathrm{a}}$ ed. Petrópolis: Vozes, 1985.

DRUMMOND, Lewis. Stanislas Du Lac: jesuit educationist and social worker (1835-1909). In: The catholic encyclopedia. Nova York: Robert Appleton, vol. 8, 1910. Disponível em: www.newadvent.org. Acesso em: 30/08/2008. 
FRANCA, Leonel. Noções de história da philosophia. $2^{\text {a }}$ ed. Rio de Janeiro: Drummond, 1921.

GONÇALVES, Paulo Sérgio L. e BOMBONATTO, V. I. (org.). Concílio Vaticano II: análise e prospectivas. São Paulo: Paulinas, 2004.

KADT, Emanuel de. Católicos radicais no Brasil. Trad. de Maria Valentina Rezende e Maria Valéria Rezende. João Pessoa: UFPB; Brasília: Inep, 2003.

LACOUTURE, Jean. Os jesuitas, volume II: O regresso. Trad. de Ana Moura. Lisboa: Estampa, 1993.

LIMA, Luiz Gonzaga de Souza. Evolução política dos católicos e da Igreja no Brasil: hipóteses para uma interpretação. Petrópolis: Vozes, 1979.

LÖWY, Michael. A guerra dos deuses: religião e política na América Latina. Trad. de Vera Joscelyne. Petrópolis: Vozes; Rio de Janeiro: LPP/UERJ; Buenos Aires: Clacso, 2000.

O’NEILL, Charles E. e DOMINGUEZ, Joaquín M. (org.). Diccionario histórico de la Compañía de Jesús. 4 tomos. Roma: Institutum Historicum Societatis Iesu; Madri: Universidad Pontificia Comillas, 2001.

PERANI, Cláudio. A prática intelectual e social dos nossos centros sociais a partir da ótica dos pobres (Decreto 4) (apontamentos). Campo, João Pessoa, fev. 1982, p. 4.

. CEAS: saudoso e saudável. Cadernos do Ceas. Salvador: Ceas, n. 185, jan.-fev. 2000, p. 89.

PERINE, Marcelo. Pe. Vaz e o diálogo com a modernidade (entrevista). IHU on line. São Leopoldo: IHU/Unisinos, n. 197, set. 2006, p. 9.

SANTOS, Francisco de Araújo. Por que Maritain? Veritas. Porto Alegre: Pontifícia Universidade Católica, n. 133, mar. 1989, p. 23-45.

SCHLESINGER, Hugo e PORTO, Humberto. Líderes religiosos da humanidade. 2 tomos. São Paulo: Paulinas, 1986.

SOUZA, Herbert José de (org.). Cristianismo hoje. Rio de Janeiro: UNE, 1962.

VAZ, Henrique Cláudio de Lima. Análise. Síntese Política, Econômica e Social. Rio de Janeiro: Instituto de Estudos Políticos e Sociais (Ieps), n. 1, jan.-mar. 1959a, p. 80-88.

. Marxismo e filosofia. Partes I e II. Síntese Política, Econômica e Social. Rio de Janeiro: Instituto de Estudos Políticos e Sociais (Ieps), n. 1, jan.-mar. 1959b, p. 29-44.

. Marxismo e filosofia. Parte III. Síntese Política, Econômica e Social. Rio de Janeiro: Instituto de Estudos Políticos e Sociais (Ieps), n. 2, abr.-jun. 1959c, p. 46-64. 
. Marxismo e filosofia. Partes IV e V. Síntese Política, Econômica e Social. Rio de Janeiro: Instituto de Estudos Políticos e Sociais (Ieps), n. 3, jul.-set. 1959d, p. 48-68.

. Cristianismo e consciência histórica. São Paulo: Escolas Salesianas, 1963. . Depoimento, 1976a. Disponível em: www.padrevaz.hpg.ig.com.br. Acesso em: 28/03/2006.

. Meu depoimento. In: LADUSÂNS, Stanislaus (org.). Rumos da filosofia atual no Brasil em autorretratos. São Paulo: Loyola, 1976b, p. 297-311.

. Humanismo e anti-humanismo em face do ensinamento social da Igreja. São Luís: Cadernos de Formação e Cultura. São Paulo: FESL; FFNSM, n. 22, jun. 1977, p. 13-25.

. Cristianismo e utopia (Anexo V). In: Idem. Escritos de filosofia: problemas de fronteira. São Paulo: Loyola, 1986, p. 291-302.

VILLAÇA,AntônioCarlos.Opensamentocatólicono Brasil.Riode Janeiro:Zahar, 1975.

WETTER, Gustav Andreas. El materialismo dialectico: su historia y su sistema en la Union Sovietica. Trad. de Eloy Terrón. 5ª ed. Madri: Tauris, 1963.

Recebido: abril/2009 - Aprovado: setembro/2009. 